\title{
Arctic Diplomacy: A Theoretical Evaluation of Russian Foreign Policy in the High North
}

\author{
Dr Vahid Nick Pay \\ Diplomatic Studies Programme, University of Oxford, Oxford, United \\ Kingdom \\ vahid.nickpay@conted.ox.ac.uk \\ Harry Gray Calvo \\ Diplomatic Studies Programme, University of Oxford, Oxford, United \\ Kingdom \\ harry.graycalvo@bfriars.ox.ac.uk
}

\begin{abstract}
International interest in the Arctic is heating up along with the planet's atmosphere and the region is increasingly presented as a new potential hotspot for inter-state competition and discord. Inevitably, Russia is often at the centre of this implicitly 'realist' narrative. This study provides an evaluation of Moscow's Arctic policy between 2000 and 2019 from an international relation theory perspective by building upon the burgeoning literature on the Arctic and sources on Russian foreign policy in general. This study postulates that several elements of Russian regional policy in the High North do indeed follow realist readings of the international politics yet it also demonstrates how structural realism fails to adequately account for the institutionalization of regional relations and, most notably, neglects the importance of domestic factors, specifically historical memory, towards understanding Moscow's contemporary Arctic policy.
\end{abstract}

\section{Keywords}

Arctic politics - Russian foreign policy - Russia High North 


\section{Introduction}

\section{$1.1 \quad$ Overview}

Popular, political, and academic interest in the Arctic is growing, as climatic changes may fundamentally reshape the region and dramatically increase its accessibility and importance to world affairs. This rising relevance indicates that further contributions to the growing academic literature on the Arctic, which remains relatively niche compared to other regions as elaborate below, could be timely and valuable, particularly from a focused theoretical perspective.

The recent trend of steady reductions in Arctic sea ice suggest that what have long-been essentially un-navigable waters for non-specialized ships could eventually become alternative and more cost-efficient routes for global shipping lanes. ${ }^{1}$ Perhaps most notably, an accessible Northern Sea Route (NSR) over Eurasia, among others, would theoretically reduce naval transit times between Europe and East Asia by as much as "40\% compared with existing shipping lanes." ${ }^{2}$ Furthermore, the US Geological Survey has tentatively "concluded that about $30 \%$ of the world's undiscovered gas and $13 \%$ " of its oil may be located near the Arctic coastline. ${ }^{3}$ These largely untapped regional reserves are also "key drivers in the accelerating interest in" and geopolitical relevance of the Arctic, as the combination of receding ice sheets with technological innovations could make them economically viable alternatives to existing sources of fossil fuels, and their sheer scale could, quite ironically, allow them to fuel global demand for "traditional" energy if and when supplies elsewhere decline. Ultimately, the possibility of new commercial routes or increasingly accessible natural resources might soon "catapult" the Arctic towards the centre of global affairs. ${ }^{4}$

1 Rob Huebert, "The New Arctic Strategic Triangle Environment (NASTE)" in P. Whitney Lackenbauer and Suzanne Lalonde (eds.), Breaking the Ice Curtain, Russia, Canada and Arctic Security in a Changing Circumpolar World (Calgary: Canadian Global Affairs, 2019): 75-93, and Michael R. Pompeo, Speech at Arctic Council Meeting Rovaniemi, Finland-"Looking North: Sharpening America's Arctic Focus." US Department of State, (May 2019) https://www .state.gov/looking-north-sharpening-americas-arctic-focus.

2 Charles K. Ebinger \& Evie Zambetakis, "The geopolitics of Arctic melt," International Affairs 85, no. 6 (2009): 1221.

3 Donald L. Gautier, Kenneth J. Bird, Ronald R. Charpentier, Arthur Grantz, David W. Houseknecht, Timothy R. Klett, Thomas E. Moore, Janet K. Pitman, Christopher J. Schenk, John H. Schuenemeyer, Kai Sørensen, Marilyn Tennyson, Zenon C. Valin, Craig J. Wandrey, "Assessment of Undiscovered Oil and Gas in the Arctic", Science 324, no. 5931 (2009): 1175.

4 Ebinger \& Zambetakis, "The geopolitics of Arctic melt", 1215-1232. 
Some commentators suggest that these developments, combined with a "globalization" of the region more generally, are leading to an increase in cooperation between its key stakeholders. ${ }^{5}$ Phenomena such as the strengthening of international legal frameworks, the Arctic Council (AC), or the increasing presence of energy multinationals, do inherently denote a sense of international cooperation, and are commonly used as examples of how regional politics, like the global picture more broadly, is moving towards interdependence and institutionalism. ${ }^{6}$

Nevertheless, other, and arguably louder voices, interpret or present these ecological changes as a prelude to a resurgent great power competition, or a frantic scramble for resources and power, based on the long-standing and seemingly inevitable primacy of national security and geopolitical interests. ${ }^{7}$

The Russian Federation (Russia) is often at the centre of these contemporary Arctic debates, and no political analysis of the region can be complete without addressing it. Firstly, by virtue of geography, Russia, with its "nearly 4,350 miles of Arctic coastline" 8 and location between both ends of the Eurasian landmass, is uniquely well placed to take advantage of any ecological, socio-economic, or geopolitical changes. Furthermore, "roughly half" of the Arctic's total population are Russian citizens and "as much as $20 \%$ of Russia's GDP" is generated North of the Arctic Circle. ${ }^{9}$ For these reasons, Russia is often seen, both by internal and external commentators, as an "exceptional Arctic stakeholder."10 The sparsely populated Arctic, with its seemingly limited number of stake-holding states, and these geophysical and economic realities, suggest that Russia should also be near the forefront of any theoretical overview of the region.

P. Whitney Lackenbauer and Suzanne Lalonde (eds.), Breaking the Ice Curtain, Russia, Canada and Arctic Security in a Changing Circumpolar World (Calgary: Canadian Global Affairs, 2019), and Oran Young, "The Arctic in Play: Governance in a Time of Rapid Change", The International Journal of Marine and Coastal Law 24, no. 2 (2009): 427.

6 Jason Dittmer, Sami Moisio, Alan Ingram, Klaus Dodds, "Have you heard the one about the disappearing ice? Recasting Arctic geopolitics," Political Geography 30, no. 4 (2011): 206.

7 Ibid. 205, and Huebert ibid.

8 United States Department of Defense, "Report to Congress on Arctic Operations and the Northwest Passage Department of Defense", https://dod.defense.gov/Portals/1/ Documents/pubs/Tab_A_Arctic_Report_Public.pdf (Accessed on 15 May 2019): 9 .

9 Andrea Charron, Joel Plouffe, Stephane Roussel, "The Russian Arctic hegemon: Foreign policy implications for Canada", Canadian Foreign Policy Journal 18, no. 1 (2012): 43. 
Russia is generally presented, in non-Arctic focused analyses, as the "classic realist power" par excellence, ${ }^{11}$ an old-fashioned state that is particularly concerned with security, geopolitics, and realpolitik. ${ }^{12}$ This interpretation of Moscow's foreign policy has been transferred to many representations of its actions in the Arctic. For instance, there was much media fanfare in 2007 when a pair of submarines planted a Russian flag on the North Pole — an event that was "widely-interpreted (...) as prima facie evidence of a return Russian realpolitik" and a confirmation that great power competition in the High North was heating up at a similar rate to the planet's atmosphere. ${ }^{13}$

Accordingly, this study aims to synthesize a diverse range of multifaceted information about the Artic, international relations in the region, and global political theories, to produce an analytical review of Russia's contemporary policies from a theoretical perspective. Hence this paper is an exercise in critically evaluating descriptive and prescriptive power of prominent theories of international politics with regard to an extremely instructive and multifaceted case study that of Russia's arctic diplomacy. It will be empirically demonstrated that while realist theories of international politics do indeed prove to have strong descriptive potentials for explaining Russia's regional policies in the High North, they fall short of adequately accounting for, not only significant ongoing liberal institutionalist trends and processes, but also overriding constructivist questions of identity that prove to be fundamental to Russia's foreign policy in the Arctic.

\section{$2 \quad$ Historical Background}

It would be challenging to attempt to understand any region or country without turning to the past. The Arctic and Russia in the early 21st century are certainly no different. Consequently, the events, policies, and discourse explored in this study should be analysed through a lens that takes the broader historical context that they stem from into consideration. Naturally it would be beyond the scope of this paper to explore all relevant topics in detail, however this section will outline an analytical historical background to our primary timeframe.

\footnotetext{
11 Maxine David, Jackie Gower, Hiski Haukkala, "Introduction: The European Union and Russia", Journal of Contemporary European Studies 19, no. 2 (2011): 184.

12 Ulrich Speck, "Russia's Challenge to the International Order", Carnegie Europe (August 2015) https://carnegieeurope.eu/2015/08/13/russia-s-challenge-to-international -order-pub-61059. 
The word "Arctic" comes from Ancient Greek and means "near the bears" (referring to the constellation rather than the animal). ${ }^{14}$ Pytheas, a Massilian navigator, is believed to have sailed to the High North (presumably Norway or Iceland) around 330 BC and his account of a "frozen sea" and "mixture of earth, water, and mist" was met with either incredulity or fear by his Mediterranean contemporaries..$^{15}$ Since then, the region has arguably retained an image (among outsiders) as a "space where fantasies and fears are performed" and a dangerous final frontier at the intersection between discovery and mystery, or opportunity and disaster. ${ }^{16}$ The fateful attempts to find and claim the "fabled sea routes to Asia"17 during the 19th Century further established these dual narratives in popular culture, and in some ways the recent Russian flag planting can be seen as another episode within them. ${ }^{18}$

In broader geopolitical terms, the unforgiving and sparsely populated nature of the region arguably gave rise to two important phenomena. Firstly, as touched upon, the Arctic was long-seen as a "frozen desert"19 or an "ice-infested buffer-zone" 20 that was consequently largely excluded, due to its harsh climate and geography, from the "hot" great power competition that characterized other regions. Secondly, the combination of its relative inaccessibility, inherent dangers, and the eventual Cold War contributed to the development of a "military culture" that continues until today, due to the "long-standing and extensive presence" of military bases and vessels in and around its waters. ${ }^{21}$

All these factors arguably contribute to the contemporary anxiety about the warming region. ${ }^{22}$ It is important to stress that the future is by nature uncertain, and that the rate of climate change in the Arctic is both unclear and expected

14 Tim Marshall, Prisoners of geography: ten maps that explain everything about the world (London: Elliot and Thompson Limited, 2015): 268.

15 R. Chevallier, "The Greco-Roman Conception of the North from Pytheas to Tacitus", ARCTIC, 37, no. 4 (1984): 342.

16 Dittmer et al., 203.

17 Scott Borgerson, "Arctic Meltdown: The Economic and Security Implications of Global Warming", Foreign Affairs 87, no. 2, (2008): 63 .

18 Dittmer et al., 203.

19 Timo Koivurova, "Limits and possibilities of the Arctic Council in a rapidly changing scene of Arctic governance", Polar Record 46, no. 2, (2010): 149 .

$20 \quad$ Charron et al., 39.

21 Paul Arthur Berkman, Environmental Security in the Arctic Ocean: Promoting Co-Operation and Preventing Conflict (Abingdon: Routledge, 2011): 86. 
to be "non-linear" in any case. ${ }^{23}$ Nevertheless, as pointed out by Wolhforth, "expectations inform policy" and all "policies are bets on the future." ${ }^{24}$ Therefore the perception of impeding change, in a "region heretofore frozen in time", 25 is vital to understanding recent events and debates.

Vladimir Putin recently stated that the Arctic has "traditionally been a sphere of our special interest." ${ }^{26}$ It is certainly no secret that Moscow has a longstanding and deep-rooted presence in the region that stretches back to its period of imperial expansion, when its Arctic holdings famously even included Alaska. ${ }^{27}$ However, it was during the Soviet era, more specifically under Stalin, that Moscow truly developed its Arctic identity and became what Andrea Charron et al. have called the "Arctic hegemon." 28

Stalin began emphasizing the "colossal wealth" of the region in his public discourse and the highly-centralized Soviet political and economic machine subsequently established itself in the High North through the creation of a specialized organization in 1932 (Glavsevmorput), which at its height employed 100,000 people, and developed Arctic infrastructure, facilities, and specialized ships on an industrial scale. ${ }^{29}$ Furthermore, it was during this timeframe that Moscow began to understand and employ the "publicity value" of the "myth of the Arctic," to the point that regional exploits became a countrywide "mania". 30 The Arctic remained an important part of the national psyche and a powerful source of prestige and propaganda throughout the Soviet period, as the UssR's greatness was illustrated by its ability to conquer the seemingly inaccessible roof of the world. ${ }^{31}$

23 Katarzyna Zysk, David Titley, "Signals, Noise, and Swans in Today's Arctic”, SAIS Review of International Affairs 35, no. 1, (2015): 177 .

24 William C. Wohlforth, "Realism and the End of the Cold War", International Security 19, no. 33 (1994): 98 .

25 Berkman, ix.

26 Vladimir Putin, Statement during meeting of the Security Council on state policy in the Arctic. Kremlin (2014), en.kremlin.ru/events/president/news/20845.

27 Lincoln E. Flake, "Forecasting Conflict in the Arctic: The Historical Context of Russia's Security Intentions", The Journal of Slavic Military Studies 28, no. 1 (2015): 72-98.

28 Charron et al., 38.

29 John McCannon, Red Arctic: polar exploration and the myth of the north in the Soviet Union, 1932-1939 (New York: Oxford University Press, 1998): 33-38.

$30 \quad$ Ibid., 111.

31 Ibid., 109. 
As a consequence of the region's broad economic, political, and cultural value, internationally, the USSR continued to assertively defend its regional claims in the Arctic, during the post-war period. The signing of the 1982 United Nations Convention on the Law of Sea (UNCLOS) arguably represented a "resounding victory" in this regard, as the simple fact that the Uss had the longest Arctic coastline meant that it benefitted the most from its Exclusive Economic Zone provisions. ${ }^{32}$ Interestingly, perhaps, the US never ratified this agreement, although it is nevertheless accepted as part of customary international law. ${ }^{33}$

In general, the global tension between the Cold War superpowers directly affected the Arctic, as the region became a heavily militarized frontline in the nuclear standoff. All the other coastal states (Canada, Denmark, Norway), as well as Iceland, were part of NATO, leaving Moscow isolated in the High North. It is worth noting that both Finland and Sweden (which, like Iceland, are not coastal states) retained a position of neutrality.

Between 1989-1991, the UssR suddenly collapsed, bringing the bipolar international system down with it. Beyond dramatically impacting Moscow's power, position, and even its sense of purpose, it also had clear repercussions in the Arctic. Many installations in Russia's northern regions fell into disrepair due to large-scale neglect ${ }^{34}$ and the high degree of militarization decreased significantly. ${ }^{35}$ This was both a product and engine of the sharp decline in global geopolitical tension, and the post-1991 period was instead characterized by an unprecedented degree of international cooperation, interconnectivity, and political optimism, ${ }^{36}$ both globally and regionally. For instance, the AC was established in 1996, bringing together the eight Arctic states (coastal and non-coastal) under the banner of cooperation and common interest, ${ }^{37}$ seemingly illustrating the region's increasingly peaceful and globalized nature. However, at the turn of the century Putin came to power. Although positive relations between the Kremlin and the West initially seemed to continue, in time, he has come to be presented as personifying a very different approach to

32 Flake, (2015): 87.

33 Michael Byers, International law and the Arctic (Cambridge: Cambridge University Press, 2013): 5 .

34 Lincoln E. Flake, "Contextualizing and Disarming Russia's Arctic Security Posture," The Journal of Slavic Military Studies 30, no. 1 (2017): 20-21.

35 Kristin Åtland, "Russia's Northern Fleet and the Oil Industry—Rivals or Partners?: Petroleum, Security, and Civil-Military Relations in the Post-Cold War European Arctic," Armed Forces \& Society 35, no. 2 (2009): 362.

36 Dittmer et al., 204.

37 Berkman, 3 . 
international politics compared to his immediate predecessors, one where the national interest is the "ultimate decider" of state policy. ${ }^{38}$

It is important to reiterate that there is a limited number of states in this region - the littoral states, Canada, Denmark, Norway, Russia, and the US, known as the "Arctic-5," and the AC members: The Arctic- 5 with the addition of Finland, Iceland, and Sweden..$^{39}$ The combination of this small "population" and the harsh geophysical conditions ensure that local powers, with an established presence and specialized capabilities, are arguably more dominant in the local international system than they, or even other regional powers, are in other regions. For instance, while "the influence of both Canada and Russia is diminishing" in global terms, in the Arctic they remain "predominantly influential" and clear heavyweights. ${ }^{40}$ Similarly, the smaller European Arctic- 5 members, Denmark and Norway, arguably have more regional clout than they do globally, although the possibility of Greenland one day becoming fully independent should be kept in mind. ${ }^{41}$ On the other hand, the US is sometimes described as a "reluctant" Arctic power, ${ }^{42}$ which, despite its considerable advantages in terms of influence and capabilities at the global scale, has been accused of "ignoring" the Arctic ${ }^{43}$ thereby undermining its potential position in the region and long-term national interests. ${ }^{44}$

38 Sumantra Maitra, "Was Putin Ever a Friend of the West? Realism and the Rise and Decline of Putin's Rapprochement with the Bush Administration after 9/11," SSRN Electronic Journal, (December 2015): 7. http://dx.doi.org/10.2139/ssrn.2704623. Andreas Kuersten, "The Arctic Five versus the Arctic Council", Arctic Yearbook, (2016). https://arcticyearbook.com/arctic-yearbook/2016/2016-briefing-notes/205-the-arctic -five-versus-the-arctic-council.

40 Byers, (2013): 280 .

41 Jørgen Taagholt, Kent Brooks, "Mineral riches: a route to Greenland's independence?", Polar Record 52, no. 3 (2016): 365 .

42 Byers, (2013): 280.

43 Borgerson, S., 2008 ibid. p. 71, In the past couple of years, the US appears to be paying more attention to the Arctic as demonstrated by recurrent declarations of the US officials some of which are reported in this paper. See the following note.

44 It should be noted that US officials seem to have recognized this relative weakness, recently indicating an intention to 'strengthen' their military, technical, and diplomatic presence (Pompeo, 2019). Trump has even expressed an interest in acquiring Greenland (ввС, 2019). 
While the end of the Cold War may have ushered a period of American unipolarity in global terms, ${ }^{45}$ in the Arctic it is Russia, for geographical and historical reasons, which holds the "privileged position", ${ }^{46}$ and could arguably be described as the regional "hegemon". ${ }^{47}$ Yet the contemporary Arctic structure should not be analysed without taking NATO into consideration, and in light of this alliance, it is clear that Moscow remains isolated. Consequently, although looking at each coastal nation's northern capabilities individually suggests that Russia is the dominant regional power, ${ }^{48}$ the fact that all other Artic-5 states are part of an intergovernmental military alliance significantly tempers its potential advantages.

Furthermore, ecological changes have led other non-Arctic powers to signal their increased interest in the region. For instance, both the EU and China applied for "observer status" at the $\mathrm{AC}^{49}$ and have openly made clear that they view the region as increasingly important to their security and economic interests. ${ }^{50}$ It seems that what was once a militarized and antagonistic, yet relatively neat and peripheral, area of world politics is indeed heating up in more ways than one.

\section{Arctic Internal Balancing}

Perhaps the most obvious way that any state can balance against a perceived external threat is simply by "mobilizing additional resources" 51 or "building up their internal capabilities." ${ }^{52}$ If we accept these simple conceptual understandings, it is clear that states are expected to "(engage) in internal balancing all the time" 53 and our region should be no different to any other. Beyond the fact

45 Kari Roberts, "Jets, Flags, and a New Cold War?: Demystifying Russia's Arctic Intentions", International Journal, 65, no. 4 (2010): 961.

46 Katarzyna Zysk, Authors' communication, 30 August 2019.

47 Charron et al., 38 .

48 Flake, (2017): 24.

49 Byers, (2013): 280 .

5o China was eventually accepted in 2013. The EU was not, although seven of its members are observers (AC, 2015); Ebinger \& Zambetakis, "The geopolitics of Arctic melt", 1230.

$5^{1}$ John J. Mearsheimer, The tragedy of great power politics, updated edition (New York: Norton, 2014): 157 .

52 William C. Wohlforth, Richard Little, Stuart J. Kaufman, David Kang, Charles A. Jones, Victoria Tin-Bor Hui, Arthur Eckstein, Daniel Deudney, and William L. Brenner, "Testing Balance-of-Power Theory in World History", European Journal of International Relations 13, no. 2 (2007): 157 .

53 Mearsheimer, ibid. 
that improved resources and capabilities might deter potential aggressors and foster economic growth, they are also a central source of a nation's power and status. ${ }^{54}$ The analysis in this section will be limited to what are arguably the two most important areas a state can focus on to generate power internally: its military and economic capabilities.

\section{$7 \quad$ Military}

The media has been quick to remind us of an Arctic militarization and Russia is often at the centre of this narrative. ${ }^{55}$ So are these claims justified? In general terms there has been a considerable development of Russia's Arctic security capabilities during our timeframe. This has particularly been the case since 2008-2009, which coincided with the release of a new nationwide "National Security Strategy" and the first post-Soviet Arctic-specific strategy, both of which emphasized the region's multifaceted strategic value and the vital need to protect it. ${ }^{56}$ For instance, multiple military bases have been modernized and several new ones built since 2007 , in what constitutes a multibilliondollar military investment project along the NSR. ${ }^{57}$ Furthermore, in 2014, a new "Northern Fleet-Unified Strategic Command" was established, which brought together previously disparate divisions into one centralized structure "responsible for protecting Russia's Arctic (industries) and national borders in the north. ${ }^{58}$ As of 2015, plans had been outlined to re-establish 10 additional Arctic airfields and set up 10 new radar facilities along the NSR, in addition to the "deployment of S-400 antiaircraft missile systems (...) and modernized MiG-31 interceptors." ${ }^{59}$ Perhaps most concerning, two thirds of Russia's naval nuclear forces are deployed in the Kola Peninsula ${ }^{60}$ and new, mysterious, and

54 Kenneth N. Waltz, "Structural Realism after the Cold War", International Security 25, no. 1 (2000): 14 .

55 Flake, (2017): 17-18.

56 Valery Konyshev, Alexander Sergunin, "Is Russia a revisionist military power in the Arctic?", Defense \& Security Analysis 30, no. 4 (2014): 327.

57 Nastassia Astrasheuskaya, Henry Foy, "Polar powers: Russia's bid for supremacy in the Arctic Ocean", Financial Times (April 2019) https://www.ft.com/content/2fa82760-5c4a -11e9-939a-341f5ada9d40.

58 Zachary Keck, "Russia to establish Arctic Military Command", The Diplomat, 21 February, (2014) https://thediplomat.com/2014/o2/russia-to-establish-arctic-military-command.

59 Zysk, Titley, 174.

6o Konyshev, Sergunin (2014): 324 . 
seemingly faulty nuclear-powered weapons have reportedly been tested in the region as these pages were written. ${ }^{61}$

Ultimately it seems that there has indeed been an "internal balancing" of Russia's Arctic military. The Kremlin has both maintained and enhanced its existing capabilities, and even innovated to a certain degree (with new defence systems including hypersonic weapons), all of which is in line neorealist expectations. ${ }^{62}$

However, although this may technically be the case, contemporary Russian military policies in the Artic should be "kept in perspective" as they are not particularly unexpected. ${ }^{63}$ Firstly, certain areas of the region have long been vital strategic security assets for Moscow for inherent geographical reasons. ${ }^{64}$ As Kobylkin, Russian Minister of Natural Resources, bluntly stated: "Russia simply doesn't have another ocean." 65 Perhaps most notably, the Kola Peninsula, and its port city of Murmansk, provides Moscow with "direct access to the Atlantic."66 Consequently its maritime forces in this area, including the nuclear-submarine fleet, are "not-Arctic specific" but arguably just "happen to be deployed (there)" due to the lack of alternatives. ${ }^{67}$

Secondly, it is important to put these developments in the context of the post-Soviet decline. While the examples listed above are "striking and demonstrate significant political resolve" some authors suggest that "they are best viewed (...) as a correction rather than a wholesale militarization." 68 Furthermore, if we also take the fact that military reforms have been occurring across Russia as a whole into consideration, the developments in the Arctic seem less alarming, as they are "roughly in line with other strategic directions" and may only be slightly greater simply because the region was "so neglected" previously. ${ }^{69}$ For instance, in 1986 Russia's Northern Fleet was made up of around 180 nuclear-powered vessels and 79 "heavy-surface-vessels" (aircraft carriers, cruisers, destroyers). By 2006 these figures had dropped to 42 and 18

61 ввС, "Rocket mystery: What weapon was Russia testing in Arctic?", British Broadcasting Corporation, (August 2019) https://www.bbc.co.uk/news/world-europe-4931916o.

62 Jeffrey W. Taliaferro, "State Building for Future Wars: Neoclassical Realism and the Resource-Extractive State", Security Studies 15, no. 3 (2006): 471.

63 Michael Byers, "Crises and international cooperation: an Arctic case study", International Relations 31, no. 4, (2017): 385.

64 Katarzyna Zysk, Valentine Deville-Fradin, "Les objectifs stratégiques de la Russie dans l'Arctique", Politique étrangère 3 (2017): 37-47.

65 Astrasheuskaya \& Foy, ibid.

66 Konyshev \& Sergunin (2014): 324.

67 Byers (2017): $385^{-3} 86$.

68 Flake (2017): 20.

69 Ibid., 21. 
respectively. ${ }^{70}$ In light of such data, Moscow's actions seem less dramatic than they might appear at first glance. ${ }^{71}$

Then, of course, the fact that the region's climate is changing is another important factor. It could be argued that Moscow is "balancing" in response to geophysical forces just as much as it is responding to potential threats from other states. For instance, the bases, airfields, and radar systems along the NSR could clearly have civilian uses as well, and if the area does see a significant increase in shipping activity, then supply-and-support posts, and policing, will inevitably be required. Ultimately, as pointed out by Stravidis, a US admiral, the "military has a rightful and necessary role in the Arctic, (as it has) equipment and personnel that can operate, survive, and facilitate access to (it)."72

Ultimately, as pointed out by Zysk and Titley, "Russian military ambitions, capabilities, and capacities have expanded significantly," and tensions with NATO arguably provided the "momentum" for this phenomenon. ${ }^{73}$

\section{8}

Economy

While the USSR was a geopolitical entity with ideological ambitions, and inherently opposed to capitalism, some commentators have suggested that Russia today ranks "among the least ideological countries" globally, where "interests" rather than "ideas" reign supreme. ${ }^{74}$ Russia has arguably developed its own brand of "bureaucratic capitalism," which combines a new drive for profit with long-standing Russian insider-networks and state-led entities, to the point that "the state itself has been privatized."75

The close links between the Kremlin and the "commercial" in modern Russia are perhaps clearest in the energy sector, where well-known giants, such as Gazprom and Rosneft, "enjoy international monopolies while being tightly controlled" by the country's political elite. ${ }^{76}$ These monopolies are a source of considerable political leverage, which has allowed Russia to become an "ener-

\footnotetext{
$70 \quad$ Åtland (2009): 373 .

71 Frédéric Lasserre and Pierre-Louis Têtu, "Russian Air Patrols in the Canadian Security and Sovereignty?", Arctic Yearbook (2016): 305-327. https://arcticyearbook.com/images/year book/2016/Scholarly_Papers/11.Lasserre-and-Tetu.pdf.

72 Berkman, $\mathrm{x}$.

73 Zysk, Titley, 174-175.

74 Dimitri Trenin, "Russia Redefines Itself and Its Relations with the West", The Washington Quarterly 30, no. 2 (2007): 95.

75 Ibid., 104

76 Roberts (2010): 964 .
} 
gy superpower" of sorts, where international influence, which was previously primarily maintained through military might, is instead projected by its oil and gas reserves. ${ }^{77}$ Putin's own academic work, written before he became President, stress the links between "state-regulated" resource extraction and the "furthering of (Russia's) geopolitical interests and maintenance of its security" in the new century. ${ }^{78}$ These writings arguably reveal a somewhat Hobbesian view of the outside world, but a version "where economic strength (and modernization) is the basis" for survival, influence, and power within it. ${ }^{79}$ All these point to Moscow's newfound "complex interdependence" with foreign states and its dependence on international energy price fluctuations.

Regardless, this updated understanding of economic affairs has been translated to the Arctic, as "Russia's approach to the region is increasingly governed by national economic interests rather than by security" concerns. ${ }^{80}$ For instance, the Kremlin's public discourse emphasizes the Arctic's resource potential and often downplays security-related issues, ${ }^{81}$ and its official "Arctic Policy until 2020" clearly described turning the region into a "strategic resource base" as Russia's primary local interest. ${ }^{82}$ As energy is an "integral" part of Russian foreign policy, some commentators have suggested that the Kremlin's renewed Arctic interest has largely been based on the region's energy potential, ${ }^{83}$ and the hope that it could fuel international demand, and subsequently maintain Russian influence abroad (and further entrench the domestic political system) as other reserves reduce. In line with these suggestions, there has indeed been a broad range of multibillion-dollar energy investments (oilfields, liquefiednatural-gas projects, and exploratory ventures) along its Arctic coast in recent years. $^{84}$

77 Robert Legvold, Russian foreign policy in the twenty-first century and the shadow of the past (New York: Columbia University Press, 2007): 426.

78 Vladimir Putin, "Mineral Natural Resources in the Strategy for Development of the Russian Economy," Problems of Post-Communism 53, no. 1 (2006): 48-54.

79 Alfred B. Evans Jr, "Putin's Legacy and Russia's Identity," Europe-Asia Studies 6o, no. 6 (2008): 900-902.

$80 \quad$ Åtland, (2009): 362 .

81 Vladimir Putin, Statement during meeting on (the) Arctic region's comprehensive development. Kremlin (official webpage in English), (29 March 2017) http://en.kremlin.ru/events/ president/news/54147.

82 (RUSFED) Russian Federation, Russian Federation's Policy for the Arctic to 2020. Translation by Arctis. (2009) www.arctis-search.com/Russian+Federation+Policy+for+the+Arctic+ to+2020.

83 Roberts (2010): 966 .

84 Moscow Times, "Russia Explores \$164Bln Worth of Arctic Projects-Reports", Moscow Times, (18 April 2019) https:/www.themoscowtimes.com/2019/04/18/russia-explores -164bln-worth-of-arctic-projects-reports-a65283. 
Throughout history, from ancient empires until the modern era, trade networks, or the ability to control them, have been a central source of power. ${ }^{85}$ It is clear that the emergence of a new route between two of the world's key economic centres (East Asia and Europe) could potentially shift the global balance of power as other routes did before it. ${ }^{86}$ Naturally, this has not happened yet, and perhaps never will, but a number of forward-looking infrastructure ventures have been, or are currently being, completed. These include a new Murmansk Transport-Hub, a new port in Sabetta-which Putin has called a "future checkpoint on this route" 87 - a network of bridges and railways along the Arctic coast, and two new gargantuan nuclear-powered icebreakers, to add to Russia's already world-leading capabilities in this regard. ${ }^{88}$ Furthermore, Russian officials describe the NSR as "our national transport artery" and legislation has been passed aiming to ensure that the state-owned Rosatom, and its fleet of nuclear-powered icebreakers, has a "monopoly over managing access" to it. ${ }^{89}$

Ultimately, it seems clear that Moscow has taken measures that can be understood to represent internal balancing in the Arctic, in terms of both its military and economic capabilities. However, it is interesting to note that it could be argued that the Russian Arctic has actually been "de-securitized" to some extent, ${ }^{90}$ at least relative to some popular portrayals of it, simply because commercial considerations appear to have taken a paramount position within Russo-Arctic policy-making. Nevertheless, the Russian economy has been sluggish in general in recent years, because of post-Crimea sanctions and low oil prices. ${ }^{91}$ This has inherently affected its Arctic regions, where construction costs are inevitably higher. Therefore, if these projects have not been particularly profitable, one should also consider their symbolic value.

85 Peter Frankopan, The Silk Roads: A New History of the World (London: Bloomsbury Publishing, 2016): 17-34.

86 Berkman, authors' communication, 6 August 2019.

87 Vladimir Putin, Statement during meeting of the Security Council on state policy in the Arctic. Kremlin (22 April 2014), en.kremlin.ru/events/president/news/20845.

88 Atle Staalesen, "These are Russia's top Arctic investments," The Barents Observer (22 March, 2016). https://thebarentsobserver.com/ru/node/612.

89 Astrasheuskaya \& Foy, ibid.

90 Åtland, 378 .

91 IIss (International Institute for Strategic Studies), "Negative outlook for Russian economy as sanctions bite," Strategic Comments 21, no. 1 (2015): 1-2. 


\section{$9 \quad$ External Signalling}

Another form that balancing could take is what Mearsheimer describes as "confrontational signalling," or the "drawing of a line in the sand," or the snow in our case, that warns would-be aggressors not to step beyond it. ${ }^{92}$ Many commentators have noted that under Putin, Russian "foreign behaviour has become more assertive" globally, possibly "marking the beginning of (such) balancing against Western power."93 Perhaps the two most concrete and controversial examples of this trend are the 2008 Georgian War and 2014 annexation of Crimea. ${ }^{94}$

While the Arctic has not seen anything remotely close to that level of escalation, there have been various cases of Russian fighter-jets "buzzing" their Western counterparts, ${ }^{95}$ a resumption of Cold War-reminiscent longrange bomber and submarine activities, ${ }^{96}$ and numerous large-scale military exercises-in fact the largest Arctic military war-game was carried out in September 2019. ${ }^{97}$ Furthermore, Russian official discourse often vigorously asserts the country's sovereign rights over its large swathes of Arctic territory ${ }^{98}$ and its military doctrine makes clear that its armed forces stand ready to defend them. ${ }^{99}$ Some commentators have noted that the direct role of the Security Council in Arctic matters "signals that there is distinct military component to

$92 \quad$ Mearsheimer (2014): 156.

93 Deborah Welch Larson, Alexei Shevchenko, "Russia says no: Power, status, and emotions in foreign policy," Communist and Post-Communist Studies 47, no. 3-4, (2014): 269-270.

94 Ibid., 270.

95 Paul Stronski, Nicole NG, "Cooperation and competition: Russia and China in Central Asia, the Russian Far East, and the Arctic," Carnegie Endowment for International Peace (28 February 2018). https://carnegieendowment.org/2018/02/28/cooperation-and -competition-russia-and-china-in-central-asia-russian-far-east-and-arctic-pub-75673.

96 Helga Haftendorn, "NATO and the Arctic: is the Atlantic alliance a cold war relic in a peaceful region now faced with non-military challenges?," European Security 20, no. 3 (2011): 338 .

97 Elizabeth Buchanan, Mathieu Boulègue, "Russia's Military Exercises in the Arctic Have More Bark Than Bite," Foreign Policy (May 2019), https://foreignpolicy.com/2019/05/20/ russias-military-exercises-in-the-arctic-have-more-bark-than-bite.

98 Ebinger \& Zambetakis, 1216.

99 (RUSEMB) The embassy of the Russian Federation to the United Kingdom of Great Britain and Northern Ireland, The military doctrine of the Russian Federation. Embassy of the Russian Federation to the United Kingdom of Great Britain and Northern Ireland (2015) https://rusemb.org.uk/press/2029. 
Russian strategic thinking." ${ }^{100}$ Even the flag-planting incident or the infrastructure projects arguably fit into this picture.

Yet it would be wrong to extrapolate definitive conclusions about such a balancing policy in the Arctic from the Kremlin's actions in other well-known regions, or even from the examples listed previously, given that, in general terms, Moscow has been keen to promote a cooperative rather than confrontational image of itself in the Arctic. ${ }^{101}$ For instance, Putin often publicly signals the value Russia places on "cooperation (with international partners) and absolute respect for international law" in the region, ${ }^{102}$ and also famously stated that "a well-proven truth has long been apparent: it is hard to survive in the Arctic alone."103 Equally, despite the actions mentioned in the previous paragraph, Russian authorities have warned against or downplayed an Arctic "military race"104 and regularly criticized NATO's presence (and its own war games) in a region where "we don't see a single issue (...) that would require a military solution."105

10

\section{External Balancing}

Another measure that can be taken by states to affect the balance of power is to create a "defensive alliance to help contain their dangerous opponents."106 However, Russia has clearly not been able to create a defensive alliance among Arctic states against the US, despite the latter's global preponderance since the end of the Cold War.

\footnotetext{
100 Nazrin Mehdiyeva, "Russia's Arctic Papers: The evolution of Strategic Thinking on the High North", NATO Defense College-Russian Studies Series 4/18, 19 (November 2018). http://www.ndc.nato.int/research/research.php?icode $=567$.

101 Zysk, Authors' communication, 30 August 2019.

102 Vladimir Putin, Statement during meeting of the Security Council on state policy in the Arctic. Kremlin (official webpage in English), (22 April 2014) en.kremlin.ru/events/ president/news/20845.

103 Vladimir Putin, Prime Minister Vladimir Putin addresses the international forum, "The Arctic: Territory of Dialogue", Archive of the Official site of the 2008-2012 of the Russian Federation, (23 September 2010) archive.premier.gov.ru/eng/events/news/12304/.

104 Zysk, Titley, 174.

105 Sergey Lavrov, Foreign Minister Sergey Lavrov's remarks and answers to media questions at the opening of the ministerial session of the 5th International Arctic Forum The Arctic: Territory of Dialogue, St. Petersburg. Embassy of the Russian Federation to Uruguay, (9 April 2019) https://uruguay.mid.ru/es/.

106 Mearsheimer (2014): 156.
} 
One could perhaps counter by returning to the points about the Arctic possibly having its own "hegemon" and suggest that the rest of the Arctic-5 are merely counterbalancing against the "menacing" Russian threat. ${ }^{107}$ It is true that despite NAто having the advantage vis-à-vis Russia in global terms, in the Arctic, Moscow arguably continues to hold the strategic edge due the fact that its "land, population, economic activity, and deployable military (and icebreaker) capacity" in the region currently "dwarf" the relative capabilities of its competitors individually. ${ }^{108}$ Consequently, one could argue that the other Arctic- 5 states are naturally inclined to coalesce in response to a common threat. ${ }^{109}$ It is also arguable that the Arctic's relative stability, compared to some other Russian "borderlands," could be explained by the fact that its coastal members are already split into two camps, which seems in line with neorealist views on "bipolar stability" and the simple idea that "uncertainty lessens and calculations are easier to make" in such a system. ${ }^{110}$ Interestingly, Mearsheimer has also suggested that the "most peaceful world would probably be one where all the great powers were insular states."111 Perhaps the fact that the Arctic Ocean separates the Arctic states is another reason why the region has remained calm.

However, NATO was not created, maintained, or expanded with the Arctic as its primary consideration. In fact, Norway has recently pushed for NATO to increase its Arctic focus. ${ }^{112}$ It is also worth noting that the Arctic-5 NATO members seem divided about the place that NATO should have within the region, as Canada apparently pushed back against a further expansion of its local activities. ${ }^{113}$ Therefore these conclusions about NATO representing a united front of the other coastal states against the "Arctic hegemon" are doubly questionable, both because they ignore the divided views of its members about the alliance's local role and do not take the broader context into account. The fact is that NATO's continued existence in these broader terms, in Europe at least, is directly opposed to realist predictions about counterbalancing.

107 Stacy R. Closson, "Kennan Cable No. 24-Russian Foreign Policy in the Arctic: Balancing Cooperation and Competition," Wilson Center (26 June 2017), https://www.wilson center.org/publication/kennan-cable-no24-russian-foreign-policy-the-arctic-balancing -cooperation-and.

108 Flake, (2017): 24.

109 Simon Collard-Wexler, "Integration Under Anarchy: Neorealism and the European Union", European Journal of International Relations 12, no. 3, (2006): 402.

110 Kenneth N. Waltz, Theory of international politics (Reading: Addison-Wesley, 1979): 168.

111 Mearsheimer (2014): 137 .

112 Julie Wilhelmsen, Kristian Lundby Gjerde, "Norway and Russia in the Arctic: New Cold War contamination?," Arctic review on law and politics 9 (2018): 399.

113 Konyshev, Sergunin, 326. 
Nevertheless, seeing as the other Arctic states are either part of a transatlantic military alliance or pursue principled neutrality, whom else could Russia turn to in order to balance against the US? Due to the contemporary fascination with China and increasing talk of a Sino-Russian rapprochement, it would be amiss not to briefly discuss how this has played out in the Arctic.

Many commentators have argued that following the collapse of the UssR, the interests of Beijing and Moscow inevitably "converged," as they both shared a similar interest in "constraining" and "counteracting" what they both perceive as "preponderant and excessive" Western power. ${ }^{114}$ This has played out through an increase in economic ties, particularly in terms of energy, ${ }^{115}$ regular coordination in multilateral diplomatic settings, and even some burgeoning military cooperation, as China participated in Vostok 2018, a large-scale military drill that was previously restricted to Russia's closest allies. ${ }^{116}$

However, in the Arctic the story seems to be slightly different. While economic ties have certainly increased, as exemplified by Beijing's Polar Silk Road project, ${ }^{117}$ some have suggested that Moscow still "tightly guards its sovereignty in the region." ${ }^{118}$ For example, Russia was initially reticent about granting China (and the EU) observer status in the AC, allegedly due to fears that it might upset the "balance of power" in "its sphere of influence," and only changed their position after Beijing had made clear that it recognised the paramount position of "Arctic states" in "Arctic affairs."119 Some authors have claimed that Moscow is uncomfortable about its position as "junior partner" in the relationship as a whole, ${ }^{120}$ and therefore it could be argued that it wants to maintain its grip over a region where it is still dominant. Nevertheless, China participated in Tsentr 2019, the large-scale Arctic military drill in September 2019.

114 Michael S. Chase, Evan S. Medeiros, J. Stapleton Roy, Eugene B. Rumer, Robert Sutter and Richard Weitz, "Russia-China Relations: Assessing Common Ground and Strategic Fault Lines-NBR Special Report \# 66," Carnegie Europe: The National Bureau of Asian Research (July 2017): 5. https://carnegieendowment.org/files/SR66_Russia-ChinaRelations_July 2017.pdf.

115 Bobo Lo, Axis of convenience: Moscow, Beijing, and the new geopolitics (Washington, D.C.: Brookings Institution Press, 2008): 173.

116 Mathieu Boulègue, "Did the Russian General Staff experiment with free play during VOSTOK-2018?," Defense And Security Analysis 35, no. 1 (2019): 103-105.

117 Henry Tillman, Jian Yang, Egill Thor Nielsson, "The Polar Silk Road: China's New Frontier of International Cooperation," China Quarterly of International Strategic Studies 4, no. 3 (2018): 346 .

118 Stronski, N.G., ibid.

119 Tom Røseth, "Russia's China Policy in the Arctic," Strategic Analysis 38, no. 6 (2014): $844-846$.

120 Chase et al., 6. 
This represented a significant shift in the recent Sino-Russian Arctic narrative ${ }^{121}$ and presumably heightened "Western sensitivities" about the Sino-Russian rapprochement. ${ }^{122}$

\section{Realism and Reality}

It should be underlined that the Arctic has not been sheltered from the forces of globalization. This is already illustrated by the increase in international interest and activity it has experienced, and the fact that its future potential, whether in terms of economic benefits or climatic catastrophe, is inherently global. ${ }^{123}$ While Russia does appear to be "internally balancing", its actions are equally part of a broader socioeconomic shift in response to an increasingly interconnected and warmer region. Furthermore, we have also seen a proliferation of non-state actors operating in the Arctic, or what one might call a "democratization of the diplomatic space."124 For instance, energy multinationals, indigenous organizations, environmental NGOS, and the international scientific community are increasingly influential Arctic actors.

Nevertheless, although some voices have suggested that "the sovereignty of states (is) disintegrating under the forces and pressures of globalization", 125 this is exaggerated. Leading capitals continue to be the key decision-makers in the Arctic, and they remain "self-centred." For instance, the 2008 Ilulissat Declaration between the Arctic- 5 emphasized the particular sovereign rights of the coastal states and ruled out a "new comprehensive international legal regime to govern the (region)." ${ }^{126}$ However, two important points should be elaborated here. Firstly, it should be noted that the Ilulissat signatories clearly pointed towards UNCLOS as the best mechanism to regulate Arctic activity, and in general it should similarly be stressed that all local states have so-far accepted that the extent of their regional jurisdiction, and their various continental shelf disputes, should be determined on the basis of existing legal

\footnotetext{
121 Buchanan \& Boulègue, ibid.

122 Zysk, Authors' communication, 30 August 2019.

123 Young, 427.

124 Raymond Saner, Lichia Yiu, "Business-Government-NGO Relations: Their Impact on Global Economic Governance," in Andrew F. Cooper, Brian Hocking \& William Maley eds., Global governance and diplomacy: worlds apart (Basingstoke: Palgrave Macmillan, 2008).

125 Shyamashree Roy, "The relevance of the Realist Paradigm in the age of globalization," Jadavpur Journal of International Relations 15, no. 1 (2011): 147.

126 (AOC) Arctic Ocean Conference, "The Ilulissat Declaration on the Arctic Ocean," International Legal Materials 48, no. 2 (2008): 382-383.
} 
rules. ${ }^{127}$ Consequently, although the "legalization" of the region has not been expanded during our timeframe, it has been maintained.

Such legal frameworks and related institutions can have a regulatory effect on state behaviour, which in turn can foster increased cooperation. This phenomenon, perhaps added to the fact that one third of Russian territory lies north of the Arctic Circle, ${ }^{128}$ has led Moscow to recognize that it "has more to gain" through upholding international laws and institutions in the Arctic than by flouting them. ${ }^{129}$ Some legal scholars have suggested that this general regional "institutionalization" has ensured that Russo-Western relations have remained more cordial and cooperative in the Arctic than else-where. ${ }^{130,131}$

Secondly, a more general point should be made about "self-interest" in an interconnected system. While it is difficult to refute neorealism's claim that any capital will look to advance its own interests above all else, international forces or actors can affect these same interests. Let us turn to what has arguably been the centrepiece of Russia's contemporary foreign policy arsenal to illustrate this.

While Russia's energy giants are a key source of international leverage, it may be interesting to recall that British Petroleum (BP) holds a $20 \%$ share of Rosneft ${ }^{132}$ and the French multinational, Total, has a similar stake in Novatek. ${ }^{133}$ More broadly, Russia was the EU's largest provider of natural gas in 2018 (at just under $40 \%$ of the overall total) and eleven of its members (mostly Eastern European) imported $75^{-100 \%}$ of their gas from Russia. ${ }^{134}$ However, at the same time, almost $75 \%$ of Russian gas exports were sold to Europe. ${ }^{135}$ This suggests that wantonly wielding its reserves as a political weapon could be highly coun-

\footnotetext{
127 Byers (2013): 281.

128 Roderick Kefferpütz, "On thin Ice? (Mis)interpreting Russian Policy in the High North," Centre for European Policy Studies, No. 205 (2010): 3.

129 Ebinger \& Zambetakis, 1215.

130 Byers, (2017): $376-378$.

131 Interestingly, the official aim of the infamous flag-planting expedition, according to Lavrov, was to prove the extent of Russia's continental shelf and strengthen its legal claims (Gerhardt et al., 2010, 966).

132 (BP) British Petroleum, Partnership with Rosneft, BP Russia (2019). https://www.bp.com/ en_ru/russia/home/who-we-are/partnership.html.

133 Nastassia Astrasheuskaya, "Total signs deal to take stake in \$2obn Novatek Arctic LNG project," Financial Times, (5 March 2019), https://www.ft.com/content/482e5938-3f3c -11e9-9bee-efab61506f 44 .

134 Eurostat, EU imports of energy products—recent developments. Eurostat (2019): 4-9, https://ec.europa.eu/eurostat/statistics-explained/pdfscache/46126.pdf.

135 (EIA) United States Energy Information Administration, Country Analysis Brief: Russia. United States Energy Information Administration (31 October 2017): 1. https://www.eia .gov/beta/international/analysis_includes/countries_long/Russia/russia.pdf.
} 
terproductive to its own economic interests. Arguably, this effectively means that both Russia and the EU, or at least its states that were once behind or near the Iron Curtain, are in a state of tentative "interdependence." ${ }^{136}$ Moscow is no longer the quasi-autarkic entity it once was. It is now integrated into the global economy (or at least partially because of post-Crimea sanctions).

Accordingly, while Russia is indeed redeveloping its Arctic regions, international investors fund some of these projects. Even though the Kremlin may be concerned about further foreign incursions into the Arctic, at the same time it has "expressed a desire" to turn the region into a "territory of partnership, cooperation, and dialogue between countries and the public at the broadest level."137

Many commentators have suggested that following the collapse of the USSR, Moscow faced, and perhaps continues to face, a severe "identity crisis." 138 Most notably, it suddenly went from being a global superpower to what Obama disparagingly described as a "regional power."139 Furthermore, it also lost the guiding ideology, or at least the moral validation, provided by communism. ${ }^{140}$ In addition, while the USSR was a multinational union, albeit revolving around Russia, post-Soviet Moscow has had to "rediscover" its Russian identity. However, due to the complexity of the Russian historical experience, "Russianness," and its relationship with the West, has long been unclear and ambivalent, at least since the time of Peter the Great, ${ }^{141}$ and possibly even earlier due to its Byzantine roots. ${ }^{142}$

136 Øistein Harsem, Dag Harald Claes, "The interdependence of European-Russian energy relations," Energy Policy 59 (2013): 787.

137 Vladimir Putin, Speech at the plenary session of the Third International Arctic Forum on the Arctic - A Territory of Dialogue. Kremlin (official webpage in English), (25 September 2013) en.kremlin.ru/events/president/transcripts/19281.

138 Evans, 899 .

139 Wilson, "Obama dismisses Russia as 'regional power' acting out of weakness," The Washington Post, (25 March 2014) https://www.washingtonpost/world/national-security/ obama-dismisses-russia-as-regional-power-acting-out-of-weakness/2014/03/25.

140 Some academics believe that the revival of the Orthodox Church was based on the need to fill this vacuum (Likhacheva et al., 2015:4).

141 Evans, ibid.

142 A. Likhacheva, Igor Makarov, Ekaterina Makarova, "Post-Soviet Russian identity and its influence on European-Russian relations," European Journal of Futures Research 3, no. 1 (2015): $1-8$. 
Several of the issues explored previously are more readily understood through a constructivist prism of identity rather than the contemporary realist regional structure. For instance, Russia's fluctuating relationship with the EU perhaps stems from this age-old cultural ambivalence rather than contemporary geopolitical realities alone. Furthermore, some have suggested that the failure of Moscow's previously lofty ideals and ambitions led it to adopt a "pragmatic",143 cynical, and perhaps even "Hobbesian"144 approach to the outside world, based on a strict (and narrower) calculation of its national interest. ${ }^{145}$ However, it could equally be argued that Russia has in fact partially rejected the fully realist identity of its predecessor. As suggested by Keohane, the autarkic, suspicious, and centralized UssR proved to be "self-defeating."146 Moscow is all too aware of this. Consequently, Russia today is business-focused and open to, even reliant on, trade and cooperation with the outside world. Its development of the Arctic and relatively "institutionalist" approach to regional politics is arguably part of a still-burgeoning global outlook and the hope that the region could maintain and expand its power in the new and increasingly interconnected century. However, despite this partial shift in identity, there is equally a considerable degree of historical inertia in Arctic politics, arguably stemming from historical memory.

Godzimirski suggested that Russia generally suffers from "the syndrome of lost empire." This author was referring to Moscow's relationship with the recently independent states, which he described as an "area of special interest" where "the presence of any external influence was seen as a challenge."147 However, these observations are similarly applicable to the warming Arctic. As mentioned, Putin has described it as an area of "special (historical) interest," and Moscow is clearly uncomfortable about an expanding foreign military presence there. Although Russia is often seen as an aggressive realist state, its foreign policy is equally constructed around a deep sense of vulnerability. ${ }^{148}$ Perhaps the many deep scars of Moscow's past, particularly those that are still recent, help understand its alleged "touchiness" 149 and emphasis on the

\footnotetext{
143 Roberts, 961.

144 Legvold, 10.

145 Trenin, 95-96.

146 Robert O. Keohane, Power and governance in a partially globalized world (London/New York: Routledge, 2002): 61.

147 Jakub M. Godzimirski, "Putin and Post-Soviet Identity: Building Blocks and Buzz Words," Problems of Post-Communism 55, no. 5 (2008): 20.

148 Andrew Monaghan, "An enemy at the gates or from victory to victory? Russian foreign policy," International Affairs 84, no. 4 (2008): 719.

149 Legvold, 10.
} 
"enhancement of its sovereignty over the macro-Arctic region." ${ }^{150}$ Moscow has certainly not forgotten the past, and it fears history repeating itself.

Nevertheless, alongside this sense of weakness, Russia is also characterized by a "residual" superpower mentality, ${ }^{151}$ also stemming from its collective memory. ${ }^{152}$ Its foreign policy is consequently assertive, occasionally emotional, and constantly interested in status. ${ }^{153}$ It is important to stress that for decades Moscow's identity was based around its perceived ability to balance Western power. As a result, its contemporary foreign policy has been "consistently influenced by a desire to reassert Russia's global status."154 The Arctic potentially offers an ideal opportunity either to finally "best the West"155 or at least to serve as a region where Moscow can continue to set the terms of global affairs. Therefore, it could be argued that its very identity as a great power is tied to it. Consequently, its Arctic policies and presence can be seen as both a way to signal its power to other states, in order to validate its status internationally, and as a way to demonstrate the enduring strength of Russia to domestic audiences. ${ }^{156}$

Olena Nikolayenko has suggested that Putin's significant domestic popularity is tied to his partial revival of Moscow's status and elements of the Soviet past (such as the national anthem), both of which advance a historical narrative and sense of nationalism based around Russia's "enduring greatness." ${ }^{157}$ It may be interesting to note, that Stalin's nationwide approval rating has improved during our timeframe, and reached $70 \%$ in $2019 .{ }^{158}$ It seems unlikely that Russian audiences would like to see Glavsevmorput recreated, or Stalinist domestic policies reinstated more broadly, however Moscow's continued ability to project strength in the Arctic, like its predecessor before it, is a significant source of "prestige" and status. ${ }^{159}$ This perhaps helps explain Russia's extensive Arctic investments and interest, even though the region is yet to be truly profitable or central to global affairs.

\footnotetext{
150 Mehdiyeva, ibid.

$15^{1}$ Trenin, 97.

152 Godzimirski, 20.

153 Larson \& Shevchenko, ibid.

154 Roberts, 961.

155 Flake (2017): 24 .

156 Stronski \& NG, ibid.

157 Olena Nikolayenko, "Contextual effects on historical memory: Soviet nostalgia among post-Soviet adolescents," Communist and Post-Communist Studies 41, no. 2 (2008): 256.

158 Moscow Times, "Stalin's Approval Rating Among Russians Hits Record High-Poll," Moscow Times, (16 April 2019) https://www.themoscowtimes.com/2019/04/16/stalins -approval-rating-among-russians-hits-record-high-poll-a65245.

159 Kefferpütz, 9 .
} 
In our case perhaps it should simply be stressed that the 1989-1991 period was a traumatic experience for Moscow. This trauma and its multifaceted effects on Russia's identity are arguably central to understanding its approach to the Arctic and the world more generally. The Arctic is consequently linked with Moscow's status concerns and broader "identity crisis."

Finally, it could be argued that Western governments have not properly acknowledged Russia's history, and therefore made "fundamental errors in managing its transition from communist empire" to a more conventional great power. ${ }^{160}$ It is important to underline that the West's own constructed perception of Moscow is also characterized by a notable degree of historical continuity. Understanding Moscow's concerns and general perspective is arguably "essential not only to understand its behaviour, but also to encourage its cooperation in global governance."161 The Arctic perhaps provides an example of a region where Russia's status and sphere of influence is not called into question and therefore Moscow acts as a committed member of the regional international substructure.

\section{3}

\section{Conclusion}

Due to the increasing international interest in the Arctic, and the recurring representation of both Russia and the region itself as evidence of a potential realist revival, this study aimed to provide a structural examination of Russia's foreign policy in the Arctic throughout the last two decades.

Over the course of the research it became increasingly clear that a range of features of Russia's regional approach and the broader substructure seemed to endorse not only paramount realist considerations but also important institutionalist and constructivist tendencies. Interestingly questions of identity and historical memory in particular proved recurrent, as a certain degree of continuity has re-emerged in Arctic politics despite the significant intra-systemic and economic changes that followed the collapse of the USSR.

Although Russia arguably holds the "privileged position" in the Arctic, Moscow has undertaken a number of "balancing" measures. Most notably there seem to have been a significant internal balancing of Russia's Arctic capabilities, both military and particularly economic, as exemplified by the substantial development of infrastructure along the NSR. Furthermore, NATO arguably

\footnotetext{
160 Dimitri K. Simes, "Losing Russia; The Costs of Renewed Confrontation," Foreign Affairs 86, no. $6(2007): 36-52$.

161 Larson \& Shevchenko, ibid.
} 
provided the "momentum" for Russia's military re-boot (and vice versa), and generally, Moscow's concerns about the maintenance of its regional sphere of influence. Nevertheless, its possible prioritization of economic development, rather than military matters, seems to go in an opposite direction. Similarly, Moscow's dual approach to external signalling and balancing which alternated between deterrence and de-escalation, was also somewhat unexpected, theoretically speaking, despite the continued existence of NATO in Europe.

Section 3 expanded upon these themes further by highlighting the fundamental importance of the institutionalization of regional politics and the growing economic interdependence of both Russia in general and its warming Arctic coast in particular. Although some have implied that regional competition is heating up at a similar rate to the planet's atmosphere, ${ }^{162}$ this is only partially provable at best, as Moscow, and other Arctic stakeholders, have generally pursued a relatively cooperative approach to regional relations, firmly based on international laws and institutions. Moscow may assert its sovereignty and signal its presence, and "discord" still exists between the region's actors, but in today's increasingly interconnected and tentatively interdependent Arctic, Russia, like others, relies more on the "institutional fabric of international society and less on individual national means" to advance its objectives. ${ }^{163}$

In addition, it would also be interesting to further explore the potential interplay between the institutionalization of Arctic politics and Russia's relative confidence about its regional status, and whether and why this may vary in other regions. This last question, and others, raises important debates about identity, as it could be argued that Russia has, contrary to some representations of it, continued to move away from the "realist identity" of its Soviet predecessor in favour of this more cooperative and notably business-focused outlook towards the outside world in the Arctic. Nevertheless, questions of identity also helped explain elements of continuity in Moscow's relations with the West in the region (and in general), as its historically induced sense of vulnerability and concerns about status, for instance, were recurrent. Historical memory in particular has played a key, yet sometimes ignored, role in shaping Moscow's Arctic policy. Most notably it helps understand why Moscow has bolstered and publicized its presence in the region, as this policy is part of its broader goal of projecting a continued image, to both international and domestic audiences, of enduring global significance and status. Consequently, it would be interesting to further explore how collective memory of these broader structural trends may explain variations in state behaviour. This could

162 Borgerson, ibid.

163 Keohane, 64-66. 
potentially complement the work of neoclassical realists on the role that domestic considerations have on the way that states understand, perceive, and interact with the anarchic international system. ${ }^{164}$

Ultimately, however, the most important question for future studies will relate to how climate change affects Arctic politics. Perhaps the unique characteristics of the changing region, where its sensitive ecosystem and extensive dangers mean that multiple areas of "common interest" exist, will contribute to a deeper level of "enhanced cooperation" between states and other stakeholders in the coming years. ${ }^{165}$ If so, the Arctic could potentially offer a framework and series of lessons about the "balancing of national and common interests" that could be applied to other regions. ${ }^{166}$ Alternatively, climate change and environmental degradation could raise the stakes, heighten competition for resources, and upset the stability that characterizes the region today. Once again, the Arctic would be a "test-site" for the international relations of the future, ${ }^{167}$ but in this case it would indeed be closer to the Hobbesian "free-for-all" that some commentators have described. ${ }^{168}$

164 Nicholas Kitchen, "Systemic pressures and domestic ideas: a neoclassical realist model of grand strategy formation," Review of International Studies 36, no. 1 (2010): 142-143.

165 Berkman, xii.

166 Ibid., 5 .

167 Dittmer et al., 208.

168 Borgerson, ibid. 